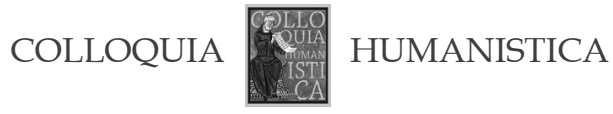

Leszek Drong

Institute of English Cultures and Literatures

University of Silesia

\title{
Post-Traumatic Realism: Representations of History in Recent Irish Novels
}

The long, venomous memory of the Celt! (O'Faolain 1980: 338)

T has become a tired cliché of the current episteme to identify historical writing with fiction. The poetics of postmodernism has abundantly fed on the linguistic/rhetorical turn in historiography associated with Hayden White, Frank Ankermit and, quite independently though perhaps equally germanely, Michel Foucault. In Ireland, however, historical, political and, to a large extent, cultural discourses seem to have resisted the Procrustean hegemony of the postmodern paradigm to the effect that the fierce debates about the factual status of the past are anything but resolved. Those debates continue on various grounds and in various venues: it is not just historians and politicians who engage in the tug of war over the received version of the nation's past. Also determined to have a say in the matter are Irish artists, who often feel responsible for ensuring a fair hearing to all sides of the debate, including the routinely marginalized voices of the politically or culturally disenfranchised sections of society. Although not necessarily committed to solid historical facts, many writers contribute unique insights related to the individual experiences of their characters, which makes their works much more engaging than the sweeping generalizations commonly offered by historians or sociologists. This 'personalization' of history is one of the chief merits of the recent Irish novels I am going to discuss below.

At the same time, I do not want to lose sight of the artistic conventions which Irish writers employ in order to stake their claims: the selection of novels used to illustrate my points conforms to a pattern I intend to isolate and define at the very outset of my argument, so that I may adequately substantiate its singular relevance to the course of Irish history in the last century. To put it in simple terms, I believe there is a direct correlation 
between specific political and social contexts alluded to in Irish fiction and the mode of writing which seems to be especially popular among contemporary Irish novelists. I identify this mode of writing as post-traumatic realism for the reasons which will be clarified further on. At this juncture it is crucial to differentiate between the predominant strategies and perspectives of the Irish writers of the last several decades and those of other Anglophone authors, be they mainstream, postcolonial, peripheral, or any other. Namely, recent Irish fiction's claim to a minority status (in a positive sense, of a unique and authentic phenomenon) consists largely in the endemic quality of its involvement in negotiating visions of its nation's past. Needless to say, those visions, by definition, reflect on the nation's future as well.

In light of the world-wide recognition and immense appreciation accorded to Irish writers over the last century it seems counter-intuitive to describe Irish literature as minor. On the one hand, Ireland belongs to a geopolitical periphery; on the other, its art and heritage feed directly into the mainstream of European (and global/ized) culture. Interestingly, John Kenny insists that what encourages a view of Ireland as "an anomalous state, a strange country" (2000: 45) is specifically the novel genre. Undoubtedly, it is necessary to further qualify my identification of Irish fiction's minority status by narrowing down the claim I make here to the kind of literature which problematizes local issues connected with the unique course of Irish history. In that, I follow the lead of the so called revisionist critics and historians who flatly oppose crude applications of postcolonial discourses to the analysis of the post-independence situation in Ireland and its sweeping comparisons with other postcolonial or neocolonial states (Foster 2001: 20). ${ }^{1}$ A detailed discussion of the contention between revisionists and postcolonial critics is beyond the scope of my essay ${ }^{2}$, but what I want to stress at this point is that my conclusions are not meant to give unqualified credence to either position. That said, the literary texts to be explored further on seem to play into the hands of those who suggest we refrain from hasty generalizations and go over individual writings and their contexts on a one by one basis.

Perhaps what underlies the widespread conviction that twentiethcentury Ireland should be seen as a victim-culture (Foster 2001: Xv) is a posttraumatic refusal to face the past as it actually was, which is epigrammatically expressed by a celebrated dictum in Joyce's Ulysses. When Stephen Dedalus,

Foster describes the British imposition of the politically correct discourse of postcolonialism on the Irish in terms of a new kind of colonial exploitation. Much in the same vein, Stephen Howe accuses cultural and literary critics of indiscriminately relying on colonial discourse analysis and Frantz Fanon's liberationist rhetoric in their discussions of Irish writers, which leads to methodological absurdities from the point of view of the historian (Howe 2000: 107-109).

2 For an in-depth discussion of revisionism in Irish historiography, see, e.g., Brown 2004: 405-409. 
the young protagonist of Joyce's opus magnum and its author's alter ego, is provoked to respond to Mr. Deasy's blatantly anti-Semitic argument about Jews being sinners against the light, he delivers an off-hand quip: "History ... is a nightmare from which I am trying to awake" (Joyce 1986: 28). Stephen is a history teacher, and the second chapter of the novel begins, not insignificantly, with a lesson on Pyrrhus. Pyrrhus' poignant victory, which decimated his own army to the extent that he was unable to oppose the Romans in another battle, is a pretext for Stephen's reflections on the recurrence of the pattern: "From a hill above a corpsestrewn plain a general speaking to his officers, leaned upon his spear. Any general to any officers" (Joyce 1986: 20). It is tempting to read Stephen's musings on the significance of Pyrrhic victories as an allusion to the condition of post-independence Ireland. The analogy, however, appears to be misleading since it would imply, in the long run, the prospect of Ireland's re-colonization. Meanwhile, over the last nine decades the political situation in Ireland has been much more nuanced than that, what with the disputed status of Northern Ireland and the gradual emancipation of the South until it became a full-fledged republic in 1949.

The fact remains that in many Irish novels written over the last few decades history is indeed portrayed as a nightmare from which numerous characters are desperate to awake. This is not to ignore the sheer variety of representations of the past in fiction: each literary work constitutes an independent vision, and, not infrequently, accommodates, side by side, diverse perspectives on history. Therefore I do not propose a single thematic category (besides their more or less explicit historical and political focus) for the novels to be discussed below. In fact, their division into three groups is dictated, a posteriori, by the choice of the examples, rather than by any prior theoretical criteria. Instead, I stipulate that the writings be distinguished by a formal characteristic which serves as a reflection of the complexity and gravity of the historical experiences in Ireland. Specifically, I want to identify those novels by their post-traumatic realism with regard to the historical and political contexts presented in their pages.

That realism and the novel go hand in hand is practically indisputable. The modern genre's origins in the eighteenth century, magisterially analyzed by Ian Watt in his The Rise of the Novel, distinguish it from among earlier modes of fiction on grounds of several formal aspects: "the particularisation of time, place and person; ... a natural and lifelike sequence of action; and ... the creation of a literary style which gives the most exact verbal and rhythmical equivalent possible of the object described" (Watt 1987: 291). In the nineteenth century, the realist novel reached its apogee in the writings of Balzac, Tolstoy and Dickens, to name just a few. What occurred in the 
twentieth century does not really amount to the demise of realist fiction although many alternative modes of novel writing came into existence due to the emergence of surrealism, magic realism, metafiction, socialist realism, antinovels and the growing popularity of fantasy and science-fiction. Many of the above mentioned developments openly break with the traditional realist conventions; some of them do so under the banner of postmodern fiction. Realism as such - with its naïve assumption about the unproblematic correspondence between the work and the world - seems to be passé and yet numerous contemporary writers continue adhering to its key protocols.

There is an interesting paradox at play in 'the return to realism' in the Irish fiction of the last few decades and the parallel erosion of the authority of historical writing to the effect that "the barriers between historical narrative, personal history and national fictions have become mobile" (Foster 2001: xix). What is often dubbed as the growing incredulity towards grand narratives seems to be immediately counterbalanced by a desire for another originary and reliable discourse. As Amy J. Elias puts it: "Once the postmodernist mind intuits or is taught by relativizing social forces that true history is unfathomable, 'history' comes to be merely 'desire' for solid ground beneath one's feet - a desire for a Blakean organized innocence, a desire for the Truth that is Out There" (2001: xviii). That would explain the epistemological leveling of history with fiction, which Linda Hutcheon describes in The Poetics of Postmodernism: both history and fiction are discourses, i.e., they "constitute systems of signification by which we make sense of the past" (1988: 89). In light of the above, Roy Foster misses the point when he complains that what Ireland needs is not historical fiction but "subversive history-writing" so that "Irish people can reinterpret their experience away from supposedly preordained patterns and endings" (2001: 21). In fact, it does not really matter what kind of discourse the Irish opt for in order to make sense of their experience as long as Ireland succeeds in what Robert Welch describes as "the business of translating itself to itself and to the outside world" (1993: viii) because it is first and foremost Irish people's future that is at stake in the business.

By dismissing literary writings Foster turns a blind eye to the subversive potential of realism which, of all the literary conventions, seems to be remarkably effective in affecting attitudes and promoting particular courses of action. Of course, his skepticism is primarily epistemological: he firmly believes in the existence of "ascertainable facts" and "a history beyond received narrative conditioning" (2001: 21), and, in his view, it is only historians who are capable of divulging those. But then, fiction - realist or any other - is not meant to make factual assertions; neither does it aspire to reproduce the past. Instead, realist fiction which is concerned with history 
offers an artistic representation of the past. The realism of the representation is a means to an end, not an end in itself, just as history is not explored for its own sake, but with a view to overcoming the postcolonial traumas not only individual predicaments but also the social, political and religious divisions which have bedeviled Irish people for the last century.

The reason why I identify a group of recent Irish novels as falling under the category of post-traumatic realism has to do with their uncompromising determination to confront Irish history and politics head-on. The historical contexts vary considerably, but most of the novels raise extraordinarily sensitive and painful issues connected with the internal conflicts in postindependence Ireland, the military and political strife in Northern Ireland, discrimination against women or the difficult situation of the Irish diaspora in the United States and in Britain. Post-traumatic realism, as an artistic convention, may be understood as an alternative paradigm of literary realism in the sense that it goes beyond strictly mimetic representations to embrace "virtual-potential realities that relate to conventional actuality in existentially complex and ethically challenging ways" (Adams 2009:2). At the same time, it enjoys most of the prerogatives of formal realism as developed in the eighteenth century: the narratives which rely on the convention elicit powerful emotional and ethical responses from their readers and retain a unique privilege of questioning the received social structures and standards. The notion of dialogism, introduced into the theory of the novel by Mikhail Bakhtin in his 1929 work on Dostoyevsky, implies that the genre is possessed of the potential to interrogate and undermine canonical stories in a given society - official versions of its history and politically sanctioned narratives of its national identity. It is all the more surprising, then, that in Ireland realist fiction should have been accused of being "implicitly collusive with an oppressively empirical or imperial centralizing mindset” (Kenny 2000: 49).

This accusation is certainly without any foundation in the case of the writings which I want to discuss in this essay. The post-traumatic realism is not a device which Irish authors use to negate their nation's history or erode Irish people's sense of identity. It is post-traumatic because the past continues to exert a paralyzing influence on the characters, and in most cases the only way to wake up from the nightmare of history is to narrate one's own version of it. Confessing, disburdening oneself, verbalizing grief, and acknowledging a grudge one holds against others are recurring themes in those novels. Even though Irish nationalists may object to the literary strategies which involve emplotment, selection and, not infrequently, a biased redaction of history, they too are responsible for manipulating the past in order to produce an idea of Ireland which conforms to their agenda (Kiberd 1996: 287-289). And yet, the difference between the nationalists 
and the revisionists (including the writers who quarry - and query - history for their settings) is crucial: the former want to fetishize and petrify the past whereas the latter reserve "the right to reinterpret [it] in the light of their desired future" (Kiberd 1996: 293). Consequently, the function of posttraumatic realism is to initiate a discussion about the nation's suppressed memories and painful experiences - whether individual or collective which are still difficult to confront as well as those which may disrupt the comfortable flow of Ireland's official historical narrative. In the long run, such confrontations are likely to eventuate in the full recovery of the people who have suffered from some of the severest traumas of modern history.

\section{Skeletons in the closet}

The first group of Irish novels I want to discuss comprises those works which illustrate the problem of historical determinism, whether it operates on a national, local or family level. In the three novels I use as illustrations of the detrimental influence of the past on the characters' present lives (Reading in the Dark by Seamus Deane, No Country for Young Men by Julia O'Faolain and The Secret Scripture by Sebastian Barry) the early years of Ireland's independence envelop dark secrets which continue to haunt innocent people simply because they are drawn into a particularly vicious vortex of historical circumstances. Their fate, like that of Tess of the d'Urbervilles, is reminiscent of ancient tragedy where superior powers (call them fatum, the Weltgeist or the Heiliger Geist) disregard the individual's desire for freedom and happiness. Moreover, the aura of imposed secrecy is often conducive to the development of various defense mechanisms, and in extreme cases, to the onset of what is diagnosed as a mental condition (both Sister Judith Clancy in No Country for Young Men and Roseanne McNulty in The Secret Scripture are considered deranged).

Chronologically, O'Faolain's novel is the oldest of the three. Published in 1980, in the heat of the Troubles in the North, it is set in deceptively peaceful Dublin. It soon turns out, however, that the city is populated by the phantoms of the past, ghastly secrets and unresolved conflicts which date to the first decades of the twentieth century. The seventy-five-year-old Sister Judith Clancy is released from her convent and takes up residence with her family who consider her half-demented. Nevertheless, her madness does not involve memory loss: it is through her narrative that the past is revealed in all its drastic clarity. Crucially, all the driving energies as well as recurring patterns of behaviour in the present seem to be overdetermined by the configuration of the past experience which culminates in Judith's confinement. As a young girl, she was fascinated by Owen, a fervent and 
dangerously idealistic republican, who was going to marry her sister. When his political visions and ambitions were imperilled by the exposure of some shady dealings to do with the American help for the Cause, Judith did not think twice and murdered Sparky Driscoll, an American who was supposed to assess the situation in Ireland and report his findings on his return home. Her myopic, emotionally motivated act has continued to haunt her in the convent and beyond; it is also directly responsible for the vicious circle of heedless crimes, infidelities and confused loyalties the Clancy family seems to be cursed with.

The book's tragic finale in the 1970s Dublin underscores another poignant aspect of recent Irish history: throughout the novel it is the women who bear the brunt of various disasters. Granted, the original crime in the story is committed by a girl but her impulse is a consequence of the accumulated antagonisms between members of the local community who variously side with the "the sea-green incorruptibles," as Judith calls them, and the more conservative pro-Treaty politicians. Young and impressionable as she is, Judith is subliminally conditioned to kill for the Cause on the strength of Owen's thinly disguised instructions (O'Faolain 1980: 316-317). Her older sister, in turn, personifies common sense and a healthy dose of realism when she exclaims excitedly:

'I've got to think of myself. And I don't give two hoots if you or anyone else thinks I'm throwing myself at Sparky Driscoll. I am. I'm in love with him. Why wouldn't I be? He's gentle. He's gay. He makes me feel I exist, and the only reason he's holding back is because everyone's been telling him that I'm to be a hero's bride. Well, I don't want a hero. I want a man.' (O’Faolain 1980: 323)

The polar opposite of Yeats's Cathleen ni Houlihan, who thrives on Irish boys' heroically sacrificed lives, O'Faolain's Kathleen aspires to break out of the prison house of history which holds every Irish person in thrall. Rather than voice a feminist agenda, she simply wants to escape Ireland, settle down, get married and enjoy family life in a peaceful country. Ironically, it is her own sister (a prefiguration of the forthcoming Civil War in which Irish soldiers will take up arms against their own brothers) who deprives Kathleen of her only ticket to a better existence.

Reading in the Dark by Seamus Deane unfolds another haunting plot in which the ghosts of the past hold sway over the protagonist's family life. Significantly, the novel's narrative convention heightens the realistic effect of the story by suspending its epistemological status half-way between autobiography and fiction. The narrator reminisces about his childhood and youth in Derry but it is not the usual joys and mishaps of adolescence that occupy centre stage in his consciousness. There is a dark secret, something 
unspoken though powerfully felt by every member of the family, which the boy is both intrigued by and afraid of. It has to do with his uncle Eddie and the turbulent years after the Civil War when the IRA mounted their military resistance to the British. In the aftermath of a violent confrontation at a local distillery, Eddie disappears and his absence seems to wound several of his relatives, especially those who are in the know and yet must not spill the secret (i.e. the boy's grandfather and then his mother). What is finally revealed involves many others as well: Eddie was executed by the IRA as an informer although he was innocent; the actual informer married the boy's aunt and when the ground started burning under his feet, much to the consternation of the entire family, he decided to abandon his pregnant wife and flee to the United States. And yet, within the Catholic community of the Bogside Derry, the records of the past are not supposed to be set straight: officially, the IRA, like the Pope, does not make mistakes.

An equally intriguing family history underlies the plot of The Secret Scripture by Sebastian Barry. Roseanne, one of its two protagonists, is a patient in a mental institution. She is nearing her death but there is one commitment which keeps her alive: she wants to leave behind the story of her life - her testimony of herself, as she puts - so that her son, who was taken away from her at birth, may learn what befell his mother. By doing so, Roseanne hopes to be reconciled both with her child and her past. Although isolated from society for blatantly nonmedical reasons (she was a moral outrage to a local Catholic priest), Roseanne does display symptoms of suppressing painful memories. Interestingly, she realizes that her sanitized version of the crucial events from her youth, which included her father's involvement in the exposure of several republicans during the Civil War in Sligo, may be questioned and objected to. However, she chooses allegiance to her memory, rather than to documented facts. Roseanne's experience informs her notion of history, too: "For history as far as I can see is not the arrangement of what happens, in sequence and in truth, but a fabulous arrangement of surmises and guesses held up as a banner against the assault of withering truth" (Barry 2008: 56). Even though deep down she may sense that she deludes herself about what her father actually did (and what she did to help him) many years ago, Roseanne knows that her oppressors are capable of willfully manipulating the facts whereby the truth about the past is doomed to be a matter of whose story is more credible. In her own case, the truth is abused in order to humiliate and demean an apparently innocent woman, therefore she is justified in mounting resistance and counteracting its venomous effect by her personal version of history.

Both The Secret Scripture and Reading in the Dark skillfully draw on the conventions which lend their plots an irresistible power and credibility. 
Their effet de réel is principally dependent on the application of confessional discourse, references to actual historical events and contexts as well as those traditional realistic devices which I discussed earlier on. Both novels, though to varying degrees, invite non-fictional interpretations. No Country for Young Men, in turn, squarely falls under the category of fiction but the apparently rambling memories of Sister Judith Clancy constitute a sly and cunning strategy: the reader is let in on a profoundly consequential secret which no other character is supposed to discover. Rhetorically, this is a masterstroke which paves the way for the willing suspension of disbelief in the artistic construction of the world presented. At the end of the day, then, the novel also succeeds in producing the effect which every realist work is defined by.

\section{The Troubles in the North}

Reading in the Dark is set in Derry, close to the border between Northern Ireland and the Republic of Ireland. The conflicts which antagonize the local community are representative of the long history of the Troubles, a period of social, political and military unrest which resulted from the arbitrary division of the island into two independent administrative units. The vociferous opposition of the republicans to the continued occupation of the North by the British forces and its status as part of the United Kingdom has been reflected in several other works of fiction. The first novel which I discuss below - Burning Your Own by Glenn Patterson - is set in Belfast in 1969. Two other novels - Bog Child by Siobhan Dowd and Eureka Street by Robert McLiam Wilson - focus on the events of the 1980s and 1990s, respectively. Bog Child draws on the hunger strike and the subsequent deaths of 10 political prisoners in the Long Kesh penitentiary in 1981; Eureka Street incorporates a shocking chapter which graphically portrays a bomb attack in Belfast. Though fictional, the bomb attack bears striking resemblance to similar assaults on innocent civilians by the IRA, especially to the Omagh massacre of August 15, 1998.

Glenn Patterson's first novel is told from the point of view of Mal Martin, a ten-year-old Protestant boy, who makes friends with a Catholic teenager by the name of Francy Hagan. Although set on a fictional estate called Larkview, the book abounds in references to actual place names in Belfast, including Ormeau, the Shankill and the Falls Road. Moreover, Patterson carefully reconstructs the heated atmosphere of the city in 1969, when the political and social tensions were about to erupt all over the North. At no point, however, does the novel give the impression that it is principally concerned with documenting a historical crisis: it is first and foremost a Bildungsroman which challenges facile stereotypes connected with religious 
allegiances and sectarian divisions. In the end, Mal refuses to identify with his own community at the expense of Francy, or, rather, his understanding of community goes beyond artificially imposed demarcation lines which are taken for granted by most people in Northern Ireland. He wants to defy historical imperatives of his times in the name of what matters to him personally - his friendship with another human being, even if the friend happens to be a Taig (i.e., an Irish Catholic).

In Bog Child, history seems to repeat itself in an endless circle of cruelty and sacrifice. The narrative relies on an analogy between internecine violence in ancient times and the Irish Catholics' refusal to acknowledge the authority of the British in the North. Fergus, the young protagonist of the novel, discovers the body of a small girl, which has been preserved in peat for many centuries. Step by step, he pieces together facts and informed conjectures about her fate to realize that she was ritually murdered by her own people. Meanwhile, Fergus's brother joins the ranks of the striking prisoners in the Long Kesh, to the dismay and despair of his mother. The family themselves are split because of their differing attitudes towards what Joey is determined to do in the name of his loyalty to the Cause: the father supports his son's decision and refuses to dissuade him from sacrificing his life. Martyrdom trumps over the prospect of yielding to a tyrant; individuals are meant to put the principles they believe in before anything else. The suffocating idealism of the republicans makes Fergus rethink his priorities. Eventually, he follows in Joyce's footsteps by choosing love and exile over an uncritical commitment to his nation. All in all, with its structure and theme reminiscent of Seamus Heaney's "Punishment", Bog Child mercilessly spells a clear message: unless you escape the Bogland (i.e., Ireland - Heaney 1998: 41), you will never transcend the vicious circle of tribal violence and sectarian divisions.

To represent the violence, bloodshed and atrocities of the conflict in Northern Ireland some writers take realist methods to their extreme. McLiam Wilson's realism in Eureka Street reaches its peak in Chapter Eleven. An episode in its own right, almost completely unrelated to the main plot of the novel, this chapter chronicles the events of a single day in Belfast, including vignettes of the lives - and painfully detailed descriptions of deaths - of several characters. In the first part of the chapter, the narrator introduces one Rosemary Daye, a young girl experiencing the joys of a new love and the subtle warmth of a sunny afternoon, and then, jolts the reader by an abrupt explosion which annihilates Rosemary alongside several dozen other casualties. Rather than simply conclude that she died on the spot, the narrator, like a pedantic psychopath, lists the injuries which the girl sustained as a result of the blast: 
The largest part of one of the glass display cases blasted in her direction. Though fragmented before it reached her, the pieces of shrapnel and glass were still large enough to kill her instantly. Her left arm was torn off by sheeted glass and most of her head and face destroyed by the twisted mass of a metal tray. The rim of the display case, which was in three large sections, sliced through or embedded in her recently praised hips and some heavy glass jars impacted on her chest and stomach, pulverizing her major organs. Indeed, one substantial chunk of glass whipped through her midriff, taking her inner stuff half-way through the large hole in her back. (Wilson 1998: 222)

What in a different context might pass for a scrupulous journalistic account of the accident is here a deliberate literary strategy which exposes the unimaginable cruelty of the people who perpetrated the murder. The narrator seems to be shell-shocked by the event: the trauma that $s /$ he identifies with makes her/him resort to an absurdly inappropriate mode of representation. What is real is magnified and aggressively imposed on the reader in order to provoke a strong emotional response. The account is not so much faithful to the facts (the explosion never occurred on Fountain Street in Belfast) as to the psychological aftermath of a face-to-face confrontation with death and violence which, for many people, constitutes a highly traumatic experience. Evidently, the realism in McLiam Wilson's representation of Irish history and politics has little to do with equanimity and disinterestedness.

\section{The collisions of the personal and the political}

The final group of writings I want to discuss here comprises several novels whose protagonists are desperate to isolate themselves from political conflicts and shrapnels of history and yet are powerless to do so. History invades their personal lives like the IRA terrorist in House of Splendid Isolation by Edna O'Brien, and the confrontation becomes inevitable. The eponymous house in O'Brien's novel, already dilapidated at the beginning of the narrative and completely ruined in the end, is richly symbolic. It is a mansion which houses all of Ireland, with its past and present, with all its sins and misguided hopes. Quite emblematically, the plot of the novel revolves round two representatives of Irish society, a woman and a man - an elderly, melancholy widow who seeks refuge from reality in her memories and a ruthless terrorist on the run. Josie O'Meara is held captive and eventually becomes the principal casualty of the circumstances which bring McGreevy to her sanctuary; McGreevy is arrested and his plan to assassinate a British politician is thus frustrated. The policemen, who accidently kill the woman while storming the mansion, are prevented from 
rejoicing, either: they realize that they "will have to answer for her death to the powers that be and answer to [themselves]" (O'Brien 1995: 210). There are no winners to exult in restoring law and justice.

By traditional, formal criteria, House of Splendid Isolation is probably the least realist novel of those discussed here, what with its self-indulgent lyrical quality and the excessive reliance on crude symbolism. Nevertheless, it is also a powerful reminder of the inevitable social and political entrapment of every individual. In Irish reality, there is no room for a Noli me tangere when it comes to the basic political divisions and identifications: no one is immune from being embroiled in the not infrequently catastrophic ramifications of the internal conflicts. Even permanent emigration does not seem to liberate one from the shackles of Irish history and politics, which is illustrated by Sebastian Barry's recent novel, On Canaan's Side. In it, Lilly Bere, a daughter of the Superintendent of the Dublin Metropolitan Police is forced to escape to the United States with her fiancé, who is unjustly accused of being an informer. Eventually, the IRA track them down all the same, and Lilly's fiancé is murdered in Chicago, while Lilly continues to fear for her life and conceal her true identity till old age. Clearly, for characters like Josie or Lilly, history is not just a nightmare; it takes the shape of a merciless assassin.

Another kind of realism (a psychological one) is masterly deployed in Breakfast on Pluto by Patrick McCabe. A bravura performance of literary ventriloquism, narrated by a transvestite prostitute, the novel is an incredibly vivid psychological portrait of Patrick "Pussy" Braden, who grows up in a fictional village of Tyreelin but soon finds the place too small to contain his exuberant personality. He is a bastard son of a local priest and his maid, raised by an alcoholic foster mother, and determined to discover the identity of his biological mother. Patrick thinks of himself as a woman, and he acts as one, which obviously scandalizes mainstream society in Ireland. But, as Tom Herron sensibly observes, the problem does not lie in the transvestite's self-identification; instead, the protagonist of Breakfast on Pluto brings into a sharper focus McCabe's "vision of postindependence Ireland as essentially a contaminated and pathological entity" (Herron 2000: 171). For example, almost grotesquely, several men Patrick is genuinely fond of disappear from his life killed, invariably, by the IRA (the politician lover, his friend Irwin, the guy he chats up in a London bar before the explosion). What distinguishes McCabe's novel from the other post-traumatic narratives of Irish history is that his protagonist never relinquishes his dreams and persists in his self-identification despite the hardships it involves in Ireland. Here again, the historical context is intermingled with the personal one, and even though they collide at times, 
"Pussy" pretends to survive all the collisions unscratched. Still, that he produces an account of his life (hyperbolically titled: "The Life and Times of Patrick Braden" - McCabe 1998: 5) on the suggestion of Doctor Terence, a therapist, may imply a more serious emotional and psychological condition than Patrick is prepared to admit to himself and to the reader.

\section{Conclusion}

There are several major reasons why Irish writers have put so much store by realistically reconstructing their history over the last few decades. For one, as Terence Brown claims, it was not until the 1960's that they were allowed to "lay full claim to the inheritance of Joycean realism" because of "the harsh facts of Irish censorship" (2010: 225). Certainly, it was also exceedingly difficult to develop a critical perspective on the events whose consequences the whole nation continued to bear for many years following its emancipation from Britain. As the twenty-first century progresses, it may bring about a gradual relaxation of the tensions, an easing of the pain and, eventually, a recovery from historical traumas. For the time being, however, those writers who live in Ireland (and those who live in Northern Ireland perhaps even more so) refuse to carnivalize their nation's past, to put it in Bakhtinian terms. They still cling to the only artistic convention which holds a serious promise of settling the score with history.

In The Rise of the Novel, Ian Watt makes a keen analogy between the expectations of the realist novel's readership and the procedures of the jury in a court of law. There are crucial epistemological parallels between the two groups: "both want to know 'all the particulars' of a given case - the time and place of the occurrence; both must be satisfied as to the identities of the parties concerned ... and they also expect the witnesses to tell the story 'in [their] own words'” (Watt 1987: 31). It is true that such analogies may be deceptive if only because fiction is ontologically incommensurable with real life. And yet fiction seems to be as credible a device for reimagining history as any other: after all, the officially authorized, fact-oriented discourses which are meant to safeguard the past's integrity are susceptible of political pressures and prone to manipulating history, too. In their thought-provoking study titled Is History Fiction? Ann Docker and John Curthoys describe a planned exhibition in the Smithsonian's Air and Space Museum in 1995, fifty years after the dropping of the bomb on Hiroshima. The curators intended to present all the historical facts, including the controversies over the decision to drop the bomb and the aftermath of the explosion (e.g., photographs of the victims) but they were effectively prevented from doing so by the powerful lobby of American veterans who 
claimed that the revisionist historians hated America and wanted to present the Japanese as victims of World War II (Docker and Curthoys 2006: 221224). That this would undermine the deeply held national narrative about the past was a sufficient reason for sanctioning an Orwellian falsification of history in a country which has always boasted of its democratic tradition.

I would not be misunderstood as concluding that, if historians and politicians are allowed to take liberties with facts, so are the novelists. Instead, the novelists are allowed to choose their literary conventions, or disregard them altogether, and the choice of realism does not oblige them to use an actual historical framework for their narratives. What I want to claim is that representations of the past in various public discourses (including the discourse of literature) should be taken for what they are - mere representations, which are always necessarily inspired by a certain vision of the future, a deliberately adopted artistic design or a current political agenda. ${ }^{3}$ Consequently, realist fiction is not a contradiction in terms; it is just an identification of certain formal qualities which predominate in particular writings. At the same time, those works which advertize themselves as nonfiction may belong to an equally problematic epistemological category.

This is the case with Angela's Ashes by Frank McCourt, an international bestseller which passes itself off as a memoir (its subtitle reads: "A Memoir of a Childhood") although its adherence to facts is highly questionable. Rather, the book explores "the traditional Irish readiness to commercialize the past" (2001: 166), as Roy Foster puts it, which is reminiscent of an béal bocht, a begging strategy ridiculed in Flann O'Brien's scorching satire The Poor Mouth. What Foster aptly observes is that, in retrospect, it is impossible to detach McCourt's memories from the literary influences and artistic conventions (including "magical realism and post-structuralist flannel" - 2001: 166) which the writer absorbed as an adult. The descriptions of extreme poverty, hunger and humiliation in Angela's Ashes are bound to be hyperbolic: already the second paragraph of the memoir leaves no doubt about the exceptional quality of the narrator's childhood. His assumption seems to be that by acknowledging his fate to have been miserable in the extreme he cannot fail to secure the reader's attention and sympathy. In the final analysis, McCourt's work, by its ostensibly non-fictional status, does the opposite of what most realist novels aspire to achieve: it smuggles in a blatantly skewed version of the past under the pretence of telling the truth and nothing but the truth.

The exceptional value of the realist fiction I have discussed in this essay does not reside in its claim to historical facts. Its particular variant which

Few historians, however, are honest enough to openly declare, the way Michel Foucault does, that they are engaged in "writing the history of the present" (Foucault 1979: 31). 
I identify as post-traumatic does not rely on the external accuracy of the actual events to those included in the plots of the books (Eureka Street is the best case in point). It is tempting to describe those works in terms of 'psychological realism' but many recent Irish novels transcend individual contexts and seem to be driven by the ambition to diagnose national traumas, as it is undoubtedly true that modern Ireland has undergone extremely painful ordeals which have left festering wounds all over its body. Even though contemporary Irish novels are not capable of ascertaining the past, much less changing its course, by encouraging readers to overcome fears, shame and prejudice, they may contribute to rewriting the present and, thereby, reworking some of the historical traumas. Therefore, as a response to the painful experience of history which is unique to Irish people, post-traumatic realist fiction is likely to play a vital part in restoring Ireland's cultural, social and intellectual well-being.

\section{References}

Adams D.

(2009) Alternative Paradigms of Literary Realism, New York.

Barry S.

(2008) The Secret Scripture, London.

(2011) On Canaan's Side, London.

Brown T.

(2004) Ireland: A Social and Cultural History 1922-2002, London.

(2010) The Literature of Ireland: Culture and Criticism, Cambridge.

Deane S.

(1997) Reading in the Dark, London.

Docker A., Curthoys J.

(2006) Is History Fiction?, Sydney.

Dowd S.

(2009) Bog Child, London.

Elias A.J.

(2001) Sublime Desire: History and Post-1960s Fiction, Baltimore - London.

Foster R.F.

(2001) The Irish Story: Telling Tales and Making It Up in Ireland, London.

Foucault M.

(1979) Discipline and Punish: The Birth of the Prison, London.

Heaney S.

(1998) “The Bogland", [in:] S. Heaney, Opened Ground: Poems 1966-1996, London, p. 41. Herron T.

(2000) “ContamiNation: Patrick MCabe’s and Colm Tóibín's Pathographies of the Republic", [in:] L. Harte, M. Parker (eds.), Contemporary Irish Fiction: Themes, Tropes, Theories, pp. 168-191. 
Howe S.

(2000) Ireland and Empire: Colonial Legacies in Irish History and Culture, Oxford. Hutcheon L.

(1988) The Poetics of Postmodernism: History, Theory, Fiction, London.

Joyce J.

(1986) Ulysses, London.

Kenny J.

(2000) "No Such Genre': Tradition and the Contemporary Irish Novel”, [in:] P.J. Mathews (ed.), New Voices in Irish Criticism, Dublin, pp. 45-52.

Kiberd D.

(1996) Inventing Ireland: The Literature of the Modern Nation, London.

McCabe P.

(1998) Breakfast on Pluto, London.

McCourt F.

(1997) Angela's Ashes, London.

McLiam Wilson R.

(1996) Eureka Street, London.

O’Brien E.

(1995) House of Splendid Isolation, London.

O'Brien F.

(1996) The Poor Mouth: A Bad Story About the Hard Life, trans. Patrick C. Power, Normal, IL.

O’Faolain J.

(1980) No Country For Young Men, Harmondsworth.

Patterson G.

(1989) Burning Your Own, London.

Watt I.

(1987) The Rise of the Novel: Studies in Defoe, Richardson and Fielding, London.

Welch R.

(1993) Changing States: Transformations in Modern Irish Writing, London.

\section{Realizm posttraumatyczny. Sposoby przedstawiania historii we współczesnych powieściach irlandzkich}

Celem niniejszego artykułu jest scharakteryzowanie głównych tendencji we współczesnej prozie irlandzkiej podejmującej tematykę historyczną i polityczną. Różnorodność tematów i postaw wobec przeszłości zmusza do wyodrębnienia co najmniej kilku odmiennych grup powieści, natomiast analiza sposobów prezentacji universum wewnątrztekstowego pozwala pokusić się o określenie jednej typowej konwencji literackiej, jaką w przypadku omawianych utworów jest realizm posttraumatyczny. Wielu 
z przytaczanych autorów wpisuje się także w nurt rewizjonizmu historycznego, który podważa zastaną narrację historyczną i obiegowy, nacechowany agresywnym nacjonalizmem model patriotyzmu. Powieści Sebastiana Barry'ego, Roberta McLiama Wilsona, Edny O’Brien, czy Julii O’Faolain kontestują ów model, ukazując, że prowadzi on do przemocy, utrwalania podziałów politycznych i stagnacji kulturowej zarówno w Republice Irlandii, jak i w Irlandii Północnej. W dobie epistemologicznego równouprawnienia dyskursu historiograficznego i fikcji literackiej omawiane w artykule powieści konstruktywnie wpisują się w dyskusję nad stosunkiem narodu irlandzkiego do swojej historii, nad koniecznością zamknięcia raz na zawsze bolesnych rozdziałów związanych $\mathrm{z}$ wojną domową początku lat dwudziestych dwudziestego wieku i konfliktami na tle społecznym oraz religijnym.

\section{Post-Traumatic Realism: Representations of History in Recent Irish Novels}

The aim of my essay is to describe major tendencies in contemporary Irish prose writing concerned with historical and political issues. The diversity of the themes and attitudes to the past necessitates a classification of the writings into several various groups of novels whereas my analysis of the modes of representing the intratextual universe paves the way for identifying a single literary convention (post-traumatic realism) which is typical of the works under discussion. Many of the quoted authors subscribe to historical revisionism which undermines the received historical narrative in Ireland and questions its aggressively nationalist model of patriotism. The novels by Sebastian Barry, Robert McLiam Wilson, Edna O’Brien or Julia O'Faolain, to name just a few, contest that model by demonstrating that it leads to violence, cultural stagnation and petrifying political divisions both in the Republic of Ireland and in Northern Ireland. In the age of the epistemological levelling of historiographic discourse and literary fiction the novels discussed in the essay meaningfully contribute to the debate over the Irish nation's attitude to their own history and the need to conclude the painful chapters of the past connected with the Civil War as well as with the social and religious conflicts of the twentieth century.

Key words: (Irish) history, realism, trauma, fiction, representation 